\title{
The effect of re-engineering of administrative operations on strategic performance. (Engistrative) Case study; Jordanian companies of mining
}

\section{Khaled Ebdah}

Department of business administration, University of taibahu. K.S.A

\begin{abstract}
This research purposes to recognize the effect of re-engineering of administrative operations( engistrative ) on strategic performance in Jordanian companies of mining ; and reach the recommendations that aim to increase the necessity of this side to ameliorate the strategic performance level in these companies from the financial sides; operational and competitive sides, this research also includes recognizing the effect of personal variables ( gender ; age ; years of experience ; administrative level and scientific qualification) on strategic performance ; whereas this research depends on the descriptive analytical curriculum ; using the questionnaire to study the opinions of sample of research that composes 55 persons like an average ( $15.7 \%$ ) from the society of research.
\end{abstract}

And this research confirms an effect with statical indication ( $a<$ 05.0) for the dimension of re-engineering of the operations ( administrative settlement ; culture of organization and readiness to change ) jointly and separately on strategic performance of mining companies .The results also approved no differences related with statical significance on the significance level ( $a>$ 05) in strategic performance of the mining companies attributed to personal and functional variables ( gender, age ), The results also approved differences related with statical significance on the significance level ( $a>05$ ) in strategic performance of the mining companies attributed to the variables (scientific qualification , scientific experience and administrative level ).

The research recommended a number of recommendations, the
Keywords:

re-engineering, administrative operations, strategic performance, strategic performance.

*Correspondence to Author:

Khaled ebdah

Department of business administration, University of taibahu., K.S.A

How to cite this article:

Khaled ebdah.The effect of re-engineering of administrative operations on strategic performance. (Engistrative) Case study; Jordanian companies of mining. Global journal of Economics and Business Administration, 2017, 2: 2.

\section{eSciencePublisher}

eSciPub LLC, Houston, TX USA. Website: http://escipub.com/ 
Khaled Ebdah, GJEBA, 2017; 2:2

most important; work on the application of the concept of operations re-engineering to increase its ability to ameliorate the strategic performance by supporting creators and motivating them , adopting their ideas, assigning them with works show their intellectual challenges and sharpen their spirit of creation, also encouraging them to be against the familiar from typical specific thinking to a thinking characterized by variety , authenticity and innovation, and changing the methods of work, its ways and its measures and increasing the attention to the human origin and work on acquiring it the appropriate technical skills which according to business requirements . In addition to the appropriate attention to raise this level and increase it. And that requires work on finding out their performance restrictions by doing more researches about this side and work on clearing it or decreasing it.

\section{Introduction}

Rapid and successive technological and economic developments and leaps are principal advantage from the advantages of our current age , which make the administrations of business organizations always trying to keep up with all is new and developed through the operations of change and continuous research for everything would achieve more proficiency and efficiency in its performance and different works, and that requires doing more modification and development to targets, facilities, methods and physical or non physical elements whereas the administrations concerned about re-engineering of the administrative operations made a continuous efforts to retest business operations and redesign it , to achieve a competitive advantage in quality , cost and customers satisfaction .

From here, using the entry of operations re-engineering is a very important step to find more effective ways and paths to discuss the problems of organizations and the experience acquired from operations re-engineering provides who are interested in improving organizations performance with new methods to face the position of institutional deterioration and make all the operations and activities of organization more efficient by joining the tasks together, shorting it and redesign it regardless of the traditional methods (Harvey \& Brown 2001) .

Whereas re-engineering of administrative operations interests in improving the strategic performance through the operations management inside the organization that focuses on the necessities of external customers by a group of employees with different skills who work together to carry out a specified task, and using the appropriate information which they need, so the organizations that have adopted re-engineering , disposed of their old methods on approaching matters, and began with new ideas and new visions ,and achieved a lot of successes to improve the performance in business organization ( el Khawaga 2008 ) .

So ,the availability of the dimensions of re-engineering of administrative operations and strategic performance is a necessity from administrative development necessities to raise the performance levels through the development of skills and abilities of the employees and members of administrative departments in the organization, whereas the development of their skills and abilities requires an effective arrangement with a spirit of team , innovation and competition whereas everyone from the employees can feel that the organization belongs to him . This feeling pushes the employees to do all of their efforts and powers and giving all they have to characterize their organization and its success.

\section{Problem of research:}

Recent and successive developments in different domains imposed on the contemporary organizations acceptance, adaptation and change with these developments, to guarantee its continuity and its interaction with the society and environment, and the effective factors around of it, but many organizations didn't assimilate change towards finding of visions and politics that interested in re-engineering of administrative operations to help it carry out its tasks, functions and its processes, so it remained in its place away from progress or success, and away from achieving its targets effectively. So this research 
is an attempt to answer the following question: Is there an effect of the dimensions of re-engineering of administrative operations (engistrative) on strategic performance in the Jordanian companies of mining?

\section{Necessity of research:}

This research is one of few researches that have linked re-engineering of administrative operations to strategic performance; this research also derives its importance through:

1. Importance of awareness and understanding the process of re-engineering of administrative operations which includes need to radically change in the method of performance to its activities and operations.

2. This research serves the Jordanian companies of mining with the information which it can offer about re-engineering of administrative operations and strategic performance, and benefit from it in training programs to achieve the targeted organizational objectives.

Objectives of research: this research aims at:

1. Recognizing the effect of the dimensions of re-engineering of administrative operations (engistrative) on strategic performance in Jordanian companies of mining.

2. Recognizing the availability of the dimensions of re-engineering in Jordanian companies of mining.

3. Recognizing the level of strategic performance in mining companies.

4. Presenting of recommendations and suggestions to decision makers in mining companies based on the results of research.

\section{Questions and hypotheses of research:}

\section{Firstly: questions of research}

First question: what are the perceptions of the research sample of the level of dominant operations re-engineering, and the availability of each dimension in Jordanian companies of mining, and these dimensions are: (administrative settlement, organization culture, and readiness to change).
Second question: what is the descending order and relative importance of the dimensions of strategic performance and speeches that measure each dimension, from the point of view of the researched?

\section{Secondly: Hypotheses of the research}

First main hypothesis: There is an effect with statistical indicator on the level of significance (a>05.0) for the dimensions of operations re-engineering (administrative settlement), organization culture, readiness to change) on strategic performance of mining companies.

First sub-hypotheses: There is a relation with statistical indication on the significance level (a>05.0) between the administrative settlement and strategic performance of mining companies.

Second sub-hypothesis: There is a relation with statistical indication on the significance level (a>05.0) between organization culture and strategic performance of mining companies.

Third sub-hypothesis: There is a relation with statistical indication on the significance level (a>05.0) between readiness to change and strategic performance of mining companies.

Second main hypothesis: There are differences with statistical indication on significance level $(a>05.0)$ in strategic performance of Jordanian mining companies employees attributed to personal and functional variables (gender, age, scientific experience, scientific qualification, administrative level).

\section{Executive definitions:}

1. Independent variable (operations re-engineering): It's a radically redesign of the activities and administrative operations, to achieve great and important improvements in cost, quality, service and speed, so it focuses on operations more than functions, and leads to concentrate on horizontal structures, team work and employees settlement (Noy, 2011, P.69)

- Administrative settlement: giving individuals a wide authority of control and taking responsibility and using their ability by encouraging them to make appropriate administrative decisions (Afandi, 2003, P.10). 
Khaled Ebdah, GJEBA, 2017; 2:2

Organization culture: group of values and basic concepts that are found and developed in work groups inside the organization and learning it to employees to determine their way of thinking, their realization and their feeling towards the internal and external work environment and determine their behavior and affect their performance and production (Abu-Bakr, 2000, P.131)

Preparing for change: Dynamic movement by following created ways and methods, arising from physical and intellectual innovations due to technical and human readiness, and it's a phenomenon hardly to avoid (Al-Otaibi and Al-Hammali, 2004, P.18).

b- Attendant variable (strategic performance): Measures that help to estimate the capacity of organization of attaching its present to its future and the extent of its acceptance to material and human resources and benefiting from it with the manner that makes it able to achieving its targets (Glunk \& Wilderom, 2000), and the strategic performance includes according to the current research the following variables:

financial performance: refer to the observation of financial laws and legislations composed in the organization and declaring the important and essential financial reports related to its works (Ebid, 2003).

Operational performance: the large concept of performance by its interesting in operational and financial processes (Safw, 2009).

Competitive performance: reflects the desire of organization of augmentation, existence and building the pioneer competitive location in the market (Naif, 2007).

\section{Precedent researches}

The results of greasing of precedent cultures and researches indicate to rareness of researches from the point of view of researcher - that search directly for the effect of the dimensions reengineering of administrative operations on the improvement of strategic performance like an applied research in Jordanian environment, so we tried to deal with some precedent researches with the same relation to achieve the targets of this research:

\section{A Arabic researches:}

Both of (Alzorayqat and Alkharsha , 2010 ) have done a research entitled "the effect of organizational learning on consolidation the dimensions of re-engineering of administrative operations ( engistrative ) in the public Jordanian establishments" , this research aims to recognizing the effect of organizational learning at consolidation the dimensions of re-engineering of administrative operations ( engistrative ) in the public Jordanian establishments and the research comes to results the most important : there is an effect of the strategic dimension of organizational learning on re-engineering of administrative operations and there is also an effect of organizational dimension of organizational learning at reengineering of administrative operations .

and ( Hanoon ,2010) has done an research entitled " the standard of using the method of administrative engineering at practicing the administrative operations in the governmental schools in the governorates of west side, from the point of view of the directors and directresses " this research aimed to measuring the standard of using the method of administrative engineering at practicing the administrative operations in the governmental schools in the governorates of west side, the research comes to several results : the total degree of the standard of using method of administrative engineering at practicing the administrative operations in the governmental schools in the governorates of west side, was high, and there are differences in the degree of using the method of administrative engineering in the administrative operations; according to the variable of scientific qualification and administrative experience .

(Alsafw 2009) has also prepared a research entitled " the elements of operations strategy and its effect at strategic performance ", aimed to determine the effect of the elements of operations strategy on the domains of strategic performance and the research came to a relation of abstract connection between the elements of operations strategy and the domains of strategic performance at the level of the general company for the manufacture of medicines and medical supplies.

As for ( Aldihany 2009 ), he has done a research entitled " administrative engistrative and the 
Khaled Ebdah, GJEBA, 2017; 2:2

possibility of its application in the educational administrations , state of Kuwait " , this research aimed to try to get to suggested conception to apply the access of administrative engistrative in the educational administrations in Kuwait, and from the results of the research the obstacles in the management of approach , professional development of teacher and administration of financial resources which called for restructuring of schools, rebuilding and change at the level school, adopting the method of participation and creative learning, assigning tasks to teachers and there is a positive correlation between personal characteristics ( position , scientific qualification and work experience ), and the axes of administrative engistrative .

\section{$\underline{b}$-Foreign researches;}

The research of Jerva ( Jerva , 2009 ) was entitled " re-engineering of administrative operations and analysis and designing the systems ", and this research aimed to check the theories of re-engineering of the operations of the main business and the similarities and differences between re-engineering of business operations , and development of information systems and discuss the requirements of re-engineering of business operations in any project to develop the information systems in different healthy sectors and human services in Australia.

The research found that the employment of techniques of re-engineering of business operations and its methods could be productive when it occurs at the same time with development of information systems, and the redesign of business operations with information technology gives the institution the probability of radically improvement to transfer the

Information and increasing the value of information in terms of content and these benefits subsequently lead to facilitate of the process of reducing cost and differentiation in products, and the last benefit until now from the integration of re-engineering of business operations, is the enablement and continuous participation of employees in making decisions

And the research of Chiplunkar (Chiplunker, et, al, 2008) entitled "application of methods of open work systems of the processes of re-engineering of administrative operations" on analysis of the environment of competitive works with the help of information technology, taking into consideration the different interactions between several business operations on applying the reengineering of business operations in German banks. And the research suggests a model based on event plans to register the logical flow and the details with the same relation which can be used in the design of information systems because the event plans is useful in the design of intelligence information systems. This methodology can be used for developing the system of designing systems, whereas each event could be analyzed to know its requirements from its data, processes and resources, and the interactions between different forces, events , models and applications through the plans of interaction and this research also searches for the dynamic powers of reengineering and its components .

The research by Francis and Kabir (Francis \& Kabir, 2008) entitled " re-engineering of human resources management in Columbia university ", aimed to analyze and determine several dimensions and sides from engineering process also the functions of human resources management; then suggest measures and standards to ameliorate information services that have been awarded to the libraries customers in seven libraries of different universities in India.

and one of the main results of the research ; human resources are the main and principal element in the success of applying modern technology in the libraries, and the key of success of engistrative in theses libraries is rebuilding of human resources and make it adopting the change of the external conditions that libraries deal with .

\section{What distinguish this research from the precedent researches?}

The research of (Alzoriqat and Alkharsha, 2010) searched the effect of organizational learning on consolidation of the dimensions of re-engineering of administrative operations; as to the research of (Hanoon,2010), searched the standard of using the method of administrative engineering at practicing the administrative operations in the governmental schools in the governorates of west side, from the point of view of the directors and directresses ". The research of (AISafw 2009) 
measured the elements of operations strategy and its effect on strategic performance. As to the research of (Naif 2007) searched the relation between knowledge management and essential capacity and its effect on strategic performance.

And we didn't find any research that discussed the dimensions of re-engineering of administrative operations and its effect on improving strategic performance in the Jordanian telecom company , as well as this research used dimensions to reengineer the administrative operations and for the strategic performance ( financial performance , operational performance, competitive performance ), and that is what distinguishes it from others .

\section{Chapter One}

Re-engineering of administrative operations and strategic performance

The first topic; re-engineering of administrative operations

\subsubsection{The concept of reengineering of administrative operations}

Several researches have used different names for the concept of process engineering, from the examples of these names: radically redesign of the operation, organizational re-engineering, restructuring of the process, determination and innovation of the process (Zairi, 1997). whereas both of Hammer and Champy ( Hammer \& Champy, 1993) define operations re-engineering as a serious and fundamental rethinking of organization operations and redesign itradically to achieve revolutionary improvements in important performance standards such as: cost, quality , service, speediness of work achievement .

And (AbdulHafiz) defined it as "radically redesign of operation to achieve big bounces in the performance" (AbdulHafiz 2003, p. 82).

It also defined as development and updating the methods of work in a way that helps to make a bounce in performance during short time (Allouzy, 2002).

Operations re-engineering can be defined as: radical redesign for systems and work methods to achieve clear results in the modern performance standards such as cost, speed, quality and level of offered service (AIRifai 2006).

Ahmed and others define it as "methodological administrative means based on organizational rebuilding from its roots, to achieve essential development for organizations performance that adopts performance speed, cost reduction and product quality" (Ahmed, et.al, 2007, P.451) .

(Hussein) also defined it as "organized logical entry to improve the administrative operations in the organization, to achieve the maximum benefit from the available physical and human resources, and to increase efficiency and efficacy of these operations" (Hussein, 2009, P.79). And based on some literature, we can clear the elements of the definition of business operations re-engineering or administrative operations reengineering as following (Olalla, 2005):

1. Fundamental: meaning that re-engineering related with the pattern of basic company work.

2. Radical: meaning that re-engineering based on ignoring all arrangements and existing structures, and thinking with new business patterns, because the superficial changes aren't useful and it should be made radically.

3. Dramatic Improvements: meaning that the amazing major changes of re-engineering should be disclosed and not marginal improvements.

4. Processes: meaning that reengineering occurs on operations and not the tasks, or functions or individuals or structures. And the Process defined as group of tasks logically connected that have been accomplished to achieve specified results, they are activities, and successive events when they are accomplished together, they produce value for customers.

By looking at the vast amount of information that discuss the concept of business operations reengineering, we can define it by this research as: great organizational transformation and radically rethinking about the operations to achieve added value to customers. Re-engineering relates to understanding and organizing the outputs, the technique of work accomplishment and organization management and its administration.

Re-engineering also relates to listening to customer, changing institutional rules and 
Khaled Ebdah, GJEBA, 2017; 2:2

organizational culture, creating material value for work, breeding learning and ideas, sharing knowledge, reshaping operations, and administrative practices.

\subsubsection{Benefits of application of administrative operations engineering}

The application of administrative operations engineering leads to many benefits for organizations, from it (Deehani 2009):

1. Providing organizations with guide about what it is trying to achieve.

2. Helping the organization to expect the changes in its environment and how to adapt with it, and consecrating the available resources and determine how to use it.

Using the entry of operations re-engineering is an important step towards finding more effective ways or methods to discuss the problems of organizations, and the utilized experiences from the approaches of operations reengineering provide the interested in improving the organizations performance with new visions to face the case of institutional deterioration , because the improvement of performance and development of organizations is no longer chosen duty that the administrations turn to or turn away from it by its own choice, but it has become essential condition for the eternity of the organization, its distinction and its non failure (Macintosh, 2003).

Some indicate to the importance of the application of administrative operations engineering, as it achieves many benefits such as (AlOtaibi and AlHammaly 2004) :

1. Clarifying the future and predicting events and preparing for it, so help the organization to prepare for its variables and taking measures to face it.

2. Advances the teamwork and makes all individuals of the organization gain experience whereas everyone participates in strategy rebuilding and setting its targets.

3. Work on expanding the organization's perceptions and its studies, and building informatics bases for different internal sides of its work, and surrounding external environment.
4. Helps to integrate and harmonize the organization activities, by developing harmonized and integrated work systems away from intersection and inconsistency.

The organizations also that adopted reengineering has disposed of its old methods of treating things, and began with new ideas and visions, achieved great successes and to improve the performance in business organizations which motivated it to be near to this entry and use it in the organizations to improve its performance (Khawaja, 2008).

And from here we can say that re-engineering of administrative operations is one of the directions that imposed itself strongly, and acquired great acceptance and augmenting attention in the last years, as a developed administrative direction by its organizational, administrative, profitable, and competitive benefits refer to the organizations on applying it, as it depends on a group of standards and specifies that aim to improve the performance of organizations in the service and productive sectors, and develop the human resources within the available possibilities, and using different methods and devices to measure and observe the improvement of product or service quality.

\section{1 .1 Objectives of re-engineering of administrative operations}

Re-engineering of administrative operations aims to improve the ineffective administrative operations, and improve the performance to fight the variables and causing a radically and fast change in the business organizations, reducing costs, achieving accomplishment of work quickly improving quality and benefiting benefit from data, select the shape and future frame of the administrative operation inside the organization, increasing positive competition between the employees and improving communication between them, and reducing the lost time of the administrative operations (AbdulHafeez ,2003).

The application of re-engineering ofadministrative operations achieves several objectives, from it: accomplishment of work quickly, reaching new ways of performance, shortening work steps, reducing degree of centralization, expanding the authorities of the employees, raising the moral spirit of employees as a result of their participation 
in making decisions, planning, innovation, creation, and encouraging take responsibility and self- control, and consolidation of positive values and directions of work (AIRifai,2006) .

From the point of view of (AIShahrani, 2007), the objectives of re-engineering of administrative operations are represented in several affairs that may affect the organization or its employees, through the following:

1. Looking ahead and determining its directions and possibilities.

2. Uniting the efforts and charging energies towards goals and aims.

3. Good investment of human resources, its energies and its knowledge, and motivate it to creation and innovation.

4. Achieving adaptation, adjustment and positive interaction with external environment.

5. Enabling the organizations and authorities to involve operating and beneficiary bodies in introducing visions, founding imaginations, and uniting efforts to achieve goals.

\subsubsection{Characteristics of re-engineering of administrative operations}

Several characteristics that characterize reengineering of administrative operations can be determined, from it : merging many functions into one function, and this of course the opposite of division of work that prevailed before, and involving the employees in making decisions, whereas the operations are multi-faces, with variation according to the work requirements, reengineering is also done for the most sensitive and important sites, and avoiding works that have no added value, depending on information technology (AIRifai 2006), and here (Mische and Bennis) sees many characteristics of reengineering of administrative operations , presented as imaginations (Mische \& Bennis 1996):

1. First visualize: re-engineering supposes that organization made all things wrongly and it must cancel everything and start again.

2. Second visualize: Re-engineering is the information technology and systems integration.
3. Third visualize: Re-engineering requires decreasing of organization size and reducing of human resources.

4. Fourth visualize: re-engineering means more efficient work with fewer resources.

5. Fifth visualize: re-engineering can solve any problem or case.

6. Sixth visualize: re-engineering can be managed and achieved by anyone.

7. Seventh visualize: re-engineering can be supported by anyone in the organization.

\subsubsection{Stages of re-engineering of administrative operations:}

Stages of re-engineering of administrative operations represented as following (Thomas, 1997):

1. Preparation stage: begin with the appropriate preparation to reach a consensus around the objectives that represent the purpose from the existence of change engineering project.

2. Innovation stage: by developing a model aims to satisfy customers' needs.

3. Visualize stage: by searching a purpose, determining available chances as visualizes of the intended radically change.

4. Solution stage: this stage divides into two stages: first, getting the technical design to apply the visualizes, and second stage the making of social design that arranges and ordering human resources that occupies the change operation function.

5. Transformation stage: by reaching and achieving operation visualizes.

While (Glunk \& Wilderom, 2000) focuses on six main stages (preparing and planning, studying the current position of operations, listening to the voice of the client, the imitation of successful models, setting the new design of operations, continuous development and application).

And (Tenant, 2005) treats six main stages of re-engineering of administrative operations: 
Khaled Ebdah, GJEBA, 2017; 2:2

1. Personification and determination of development domains: this step examines the current position of organization and recognizing the degree of customer satisfaction about goods and products.

2. Planning stage (preparing a map for current operations) : this step begins with drawing illustrative maps of operations of organizations and giving specific names to these operations (buying operation, storage, manufacturing and selling), whereas the team of re-engineering examine this operation severally and choosing the defective, old and inappropriate operations that cause problems, lack of quality and high costs .

3. Determining necessary modifications (internal analysis): this is the most important stage of business re-engineering, in which the required change of studied processes is determined, and the new ideas of operations modification appear in the following sides: increasing speed of operations, shorten the number of steps per process, canceling the steps of high costs, raising the level of operation quality, and augmentation performance proficiency.

4. Imitation successful models: by recognizing the best applications in similar organizations, to guide and benefit from the achievement of these organizations.

5. Operations redesigning: by broaching more than alternative that achieve number of conditions, these alternatives achieve a future vision of project that can be achieved within the company's capabilities, and leading to a qualitative leap and massive changes, and it can be less expensive when applied, and achieve the customers' desire, and then the comparison between these alternatives is done and choosing the best, the fastest, the most accurate and the perfect from it.

6. Application and follow-up: putting the new plan into practice and here stuff must be trained on new operations until it is executed with the minimum errors, it also requires continuous follow-up to measure the initial results and determine the degree of its efficiency on achieving the required targets.

\subsubsection{The dimensions of re-engineering of ad-} ministrative operations
Re-engineering of administrative operations has several dimensions that its effects vary from an organization to another, and from an establishment to another, and despite the lack of agreement between the researchers about the dimensions of re-engineering of administrative operations and the importance of each dimension, but few studies discuss the dimensions in their detailed form or treat their on several manner, and it is worth mentioning that the dimensions of re-engineering of administrative operations in this research are:

\section{Enalement of employees:}

Enablement is a very important element from the elements of the vitality and continuity of organization, because it contributes to raise the morals and satisfaction of the employees, as they feel the opportunity to show their abilities, they also enjoy the respect of organization and its trust, this satisfaction contributes with the freedom of the behavior guaranteed to the enrichment of creative thinking and pursuit to improve the performance, the enablement also leads to fast treatment of complaints, suggestions and problems of customers inside and outside, and it is an essential factor for the success of organizations and its continuity, successful factor especially the organizations became in ascending competitive environment (Al-Zidanieen 2006), and (Afandi ,2003) indicated to group of benefits and positives that the organization can achieve by enablement and the most important: encouraging the individual to innovation, initiative, commitment of team spirit, loving adventure, making decisions in the most appropriate levels, facilitating management performance (faster and more flexible reaction to customer requirements), achieving high levels of self-confidence and motivation of employees, and achieving great awareness of needs of organization and needs of employees, helping in reducing costs and improve quality, increasing the readiness of organization for rapid interaction with variables and increasing employees' satisfaction.

From the methods that the management can enable its employees by it:

expressing the confident of management in the capabilities of employees, also its expression on its wishes and high expectations that related with the capabilities of employees and their level 
Khaled Ebdah, GJEBA, 2017; 2:2

of performance, increasing their contribution in making decision, giving them freedom and independence in choosing the appropriate ways to execute their business and contribute in setting up and determining their ambitions and targets, the administrative authorities use authority and domination rationally and in a positive manner and limiting the using of force and coercion (Afandi, 2003).

\section{Organizational culture:}

Organizational culture has an essential function in controlling and supervision on behavior; because it makes on creating supervisor system and social control, this system determines to the individuals the right behavior and manners, and effects on its performance inside the organization, and the effect of culture reflects on performance in achieving higher production levels or achieving competitive advantages or achieving high financial performance, and (Al-Khalifa, 2008) indicated to the strong positive organizational culture is one of the principal elements which contribute to achieve high performance level through group of cultural components, that can achieve high performance level and from it:

1. Going to change and encouraging innovation and creation.

2. The existence of clear vision and clear direction that achieves the agreement on targets and objectives.

3. Clear and strong values and standards that turn to motivational force of behavior.

4. Paying attention to individuals like an important cultural element that pushes individuals to trust in fairness of evaluation.

5. Paying attention to team work and co-operation between individuals represents an important and effective cultural component in achieving high and distinctive performance level.

While that (El-Morsy and Idris,2002) indicate to the importance of organizational culture may exist in the group of roles or purposes played in the organization, and from it: the role of culture is the guide for individuals and activities in the organization to aim mind and efforts to achieve the objectives of the organization and its vocation, and determine the method and speed of organization individuals response to movements of competitors and needs of customers that achieve the existence of organization and its growth, and achieve the internal completeness between the individuals of organization by recognizing them how to communicate between them and work together effectively, and achieving adaptation between the organization and external environment, by recognizing the employees with needs and necessities of the parties in external environment who are related to the organization.

And based on the previous, we can say that the importance of organizational culture exists in finding feeling and sense of identity for members, and helping to create commitment between them as a guide to the appropriate behavior, it facilitates the process of re-engineering of administrative operation and enhances the stability and balance of organization as a social system, and works as an alerting to form the guidance of individual and community behavior.

\section{Readiness for change:}

The process of change is a continuous and interconnected process, so when an organization adopts change and its problems personification, it can't stop at this point, but it has to take the most important step and it is the stage of actual and practical application of change, and when the organization decides doing modification or essential change in its activities, it will usually face great risks relate to change its culture and its performance level (Daft, 2001).

Readiness for change requires investment of resources in terms of time, effort and money, whereas the achievement of change effectively requires preparation and giving physical and human potentials to support change, and (Morris and Roben, 1995) see the importance of determining and saving physical and human resources and process of training and development during the various stages of change.

One of the most important roles of authorities during process of change represents in helping those who affected by change to adapt to the environment and conditions of uncertain created by change. And on the same time the authorities must work on ensuring that change goes according to plan. Change can be seen as a long term and planned effort and activity, aim to change 
Khaled Ebdah, GJEBA, 2017; 2:2

the organization culture in order to continuous improvement to its ability on developing its vision and increasing the quality of its performance and its production, and innovating itself by participation and co-operation of its employees to achieve its objectives and its vocation (El-Edeely, 1995).

Change is only an organized pattern of human efforts towards conflict with existing constraints and limitations, and removes it and effect on it to achieve several important benefits to organization and new forms of relations (Al-Khodiry, 2003).

So that organizational change achieves its goal, it must be organized work based on previous planning which seeks to face certain needs and achieves specific needs. And there is an important reality, is that the success of a certain plan of change in an organization doesn't necessarily mean its success in other organization, but the appropriate plan of change must be made in a view of accurate personification to its problems and its conditions of work (Boume, 2006).

Change and organization rebuilding are tow processes which depend on responsibility of planning and application, and ensuring that any changes in any level and in any activity achieved a success and progress in the work and performance. So the decision of change usually begin from the highest authority and the desire of senior management in changing the current method towards development and updating that consistent with competitive and existing changes, so the change raises productive proficiency of work, and opens the door of innovation and creativity, and changes the administrative operations in their all forms and on all levels towards a work environment more dynamic and more intertwined and connected (Smith, 2001).

\section{Second topic: Strategic performance}

\subsubsection{The concept of performance:}

The concept of performance links to both of individual and organization behavior and occupies a special place inside any organization as the final output of all its activities on the level of individual, organization and country, and there are several definitions of researchers to performance, so performance indicates to the sum of human behavior in the light of procedures and techniques that guide the work towards achieving the desired objectives (Al-Rabeeq, 2004).

And despite the difference between researchers in the performance definition, but there are factors that compose these definitions, and they are as following (Al-Sagheer, 2002):

a. Employee: and his knowledge, skills, values, bearings and motives.

b. Function: and its requirements, challenges and what it offers from opportunities.

c. Situation: what is the organizational environment characterized by that includes work environment, supervision, administrative systems and organizational structure.

Whereas strategic performance is achieved by the human resources, devices, machines, physical resources and technology (information, methods, manners), the performance also achieved to these elements in an organizational framework determined by an organizational structure, policies and rules, systems, and procedures, and institutional performance links to the system $(7-S, s)$ that is related to the pillars of strategic performance that include the existence of values and principals, strategy, structure and style that agree with vision of company, systems, staff, and continuous development of skills that is necessary to the performance of work company (Banker et al, 2009).

And here we see that the concept of performance is the activity of employees by doing duties, tasks and responsibilities which they must do in their functional position, and the perfect performance is doing duties, tasks and responsibilities to the fullest.

\subsubsection{Levels of performance}

Strategic performance is comprehensive concept and integrated system with several sides, and according to this view, strategic performance is at several levels and they are (Al-Kotb, 2002):

1. Individual level (performance of employees, human resources, human capital, intellectual capital).

2. Partial functional level (performance of organizational units in the framework of public policies). 
3. Total level, performance of organization in the framework of economic, social and cultural environment.

And (Naif) indicates that strategic performance is the integrated system of the results of business organization in the light of their interaction with the elements of their internal and external environment and it includes the individual performance in their organizational units, the performance of organizational units in the framework of public policies of organization, and performance of institution in the framework of economic, social and cultural environment (Naif, 2007).

\subsubsection{Reasons for interesting in strategic per- formance}

Most researchers agree on determining the reasons for concentration of organizations to achieve perfect strategic performance due to its importance to it through the following:

1. Organizations need to methods and manners to recognize the obstacles that it

Faces if it will appear.

2. Organizations need to a method to collect information to be able to make important decisions about human resources.

3. Organization needs to develop its members continuously whether managers or employees, to be able to make the organization more distinguished in performance compared to competitive organizations.

4. Organization needs to save the necessary skills to the decision maker whether an individual or group, and looking at the sensitivity of the role he plays and it's important in achieving creativity and distinguish in the organizations.

\section{Chapter II}

\section{Methodology and design}

\subsection{Research style:}

This research depends on descriptive analytical method, and field study method, and it derived its information and data from two sources:

1. Secondary prepared sources, represented in specialized scientific books, articles, universi- ty researches, and previous researches in this field. As it was a comprehensive embrocating of the available office-sources about the subject of this research.

2. Primary sources, represented in data which were collected by a questionnaire prepared for this purpose, and the list has been tested before using it in the research, it also has been designed to obtain three kinds of data: functional and personal data of employees, dimensions of processes re-engineering data, and data of measuring the level of strategic performance.

\subsection{Research community:}

The research community includes workers in Jordanian companies of mining from all administrative levels with (350) employees in light of statistics of employees affairs in researched companies. And the individuals of research community are distributed as follows:

Table no. (1.2): Numbers of research community

\begin{tabular}{|l|l|l|l|}
\hline Company & $\begin{array}{l}\text { Number of em- } \\
\text { ployees } \\
\text { Total }\end{array}$ & $\begin{array}{l}\text { Number of distrib- } \\
\text { uted questionnaire }\end{array}$ & $\begin{array}{l}\text { Number of re- } \\
\text { trieved question- } \\
\text { naire }\end{array}$ \\
\hline $\begin{array}{l}\text { Mining com- } \\
\text { panies }\end{array}$ & 350 & 55 & 49 \\
\hline
\end{tabular}

\subsection{Sample of research:}

An appropriate sample has been chosen from the research community which composed of (350) person, as the number of sample members was (55) persons which form an average $(15.7 \%)$ from the research community, and (55) questionnaires have been distributed, and (52) questionnaires have been retrieved as an average $(94.5 \%)$ from the research sample, and (3) questionnaires have been excluded because they are not valid for analysis, and for that (49) questionnaire have been analyzed as the average $(89 \%)$ from research sample, and the following is a presentation of the characteristics of research, according to personal and functional variables:

Table no. (2.2)

Description of characteristics of research sample

According to functional and personal variables

\begin{tabular}{|l|l|l|l|}
\hline Variable name & Variable category & Repetition & Average \\
\hline
\end{tabular}




\begin{tabular}{|c|c|c|c|}
\hline Gender & $\begin{array}{l}\text { Male } \\
\text { Female }\end{array}$ & $\begin{array}{l}45 \\
4\end{array}$ & $\begin{array}{l}91.8 \% \\
8.2 \%\end{array}$ \\
\hline Age & $\begin{array}{l}30 \text { years or less } \\
31-35 \text { years } \\
36-40 \text { years } \\
41 \text { years or more }\end{array}$ & $\begin{array}{l}9 \\
25 \\
7 \\
8\end{array}$ & $\begin{array}{r}18.3 \% \\
51.0 \% \\
14.3 \% \\
16.4 \% \\
\end{array}$ \\
\hline $\begin{array}{l}\text { Scientific qualifi- } \\
\text { cation }\end{array}$ & $\begin{array}{l}\text { High school or less } \\
\text { Diploma } \\
\text { BA } \\
\text { Master's degree }\end{array}$ & $\begin{array}{l}7 \\
5 \\
27 \\
10\end{array}$ & $\begin{array}{r}14.3 \% \\
10.2 \% \\
55.1 \% \\
20.4 \%\end{array}$ \\
\hline $\begin{array}{l}\text { Practical experi- } \\
\text { ence }\end{array}$ & $\begin{array}{l}5 \text { years or less } \\
6-10 \text { years } \\
11-15 \text { years } \\
16 \text { years and more }\end{array}$ & $\begin{array}{l}4 \\
20 \\
15 \\
10\end{array}$ & $\begin{array}{l}.2 \% \\
40.8 \% \\
30.6 \% \\
20.4 \%\end{array}$ \\
\hline Functional level & $\begin{array}{l}\text { Manager } \\
\text { Assistant manager } \\
\text { Head of department } \\
\text { Employee/ worker }\end{array}$ & $\begin{array}{l}2 \\
5 \\
15 \\
27\end{array}$ & $\begin{array}{l}.1 \% \\
10.2 \% \\
30.6 \% \\
55.1 \%\end{array}$ \\
\hline
\end{tabular}

Table no. (2.2) illustrates that the number of males more than females, as the average of males is $(91.8 \%)$. and this reflects the actual reality of the path of the workforce in Jordanian organizations, because the averages of males is always higher than the averages of females, especially if it is attached to professions that need great effort and difficult work conditions, as in mining and extraction companies.

and regarding to the age variable, the category of (31-35) years as an average $(51 \%)$ is the superior, then the category (30 years or less) as $(18.3 \%)$, and this is logic, because this professions require a great effort and working in difficult conditions and for long hours. so it needs the element of youth with middle ages.

As for the scientific qualification variable, the high average was (BA) category as (55.1\%), to reflect the predominant scientific experience in all of Jordanian institutions and companies, then the category (high degree) as (20.4\%), and the category ( diploma) came in the last class as $(10.2 \%)$.

And regarding to the practical experience, the category of $(6-10)$ years is the predominant as an average (40.8\%), and this is normal because the experience is linked to the average of employee's ages, as the high rate of workers ages in the sample is for the age category (31-35).

And as for the functional level, the category (employee, worker) is the high rate as $(55.1 \%)$ from the whole sample.

\subsection{Research tool}

The research tool has been crystallized by looking at the theoretical side's background of the research variables and dimensions (independent and attendant),

which is related to processes re-engineering and strategic performance, as well as standing at the tools of the previous researches to get benefit from its available data in this research, as the researcher developed a comprehensive questionnaire to the research subject with its variables and dimensions, to measure the dimensions of operations re-engineering and strategic performance, and as following a detailed illustration with its parts and paragraphs:

Part one: includes functional and personal information of employees and they are variables (gender, age, functional experience, scientific qualification, administrative level).

Second part: composed of (9 paragraphs), as (3) paragraphs for each dimension, to measure the dimensions of operations re-engineering which are represented in (administrative settlement, organization culture, readiness for change).

Third part: composed of (9 paragraphs), as (3) paragraphs for each dimension, to measure the variable of strategic performance which represented in (financial performance, operational performance, competitive performance).

And the answers of paragraphs of this questionnaire are designed on the Likert scale of the five degrees whereas they were as following: (5 degrees) for strongly agree, (4 degrees) for agree, (3 degrees) for agree with medium degree, (2 degrees) for disagree, (1 degree) for strongly disagree.

And table no.3 illustrates the variables of research and its dimensions and the paragraphs that measure each dimension. 
Khaled Ebdah, GJEBA, 2017; 2:2

Table no. (3.2): the variables of research and its dimensions and the numbers of paragraphs that measure each dimension

\begin{tabular}{|c|c|c|}
\hline Variable & Dimension & $\begin{array}{l}\text { the numbers of para- } \\
\text { graphs that measure } \\
\text { each dimension }\end{array}$ \\
\hline $\begin{array}{l}\text { Operations re-engi- } \\
\text { neering (independent } \\
\text { variable) }\end{array}$ & $\begin{array}{l}\text { Administrative settlement } \\
\text { Organization culture } \\
\text { Readiness for change }\end{array}$ & $\begin{array}{l}1-3 \\
4-6 \\
7-9\end{array}$ \\
\hline $\begin{array}{l}\text { Strategic performance } \\
\text { (attendant variable) }\end{array}$ & $\begin{array}{l}\text { Financial performance } \\
\text { Operational performance } \\
\text { Competitive performance }\end{array}$ & $\begin{array}{l}10-12 \\
13-15 \\
16-18\end{array}$ \\
\hline
\end{tabular}

\subsection{Stability of research tool}

Stability factor was extracted, according to (Cronbach's Alfa) of internal consistency in its full final form, and for each variable (independent and attendant) with its all dimensions, and the results were as in the following table (4.2):

Table no. (4.2): value of stability factor of internal consistency for each variable (independent and attendant) with its all dimensions.

\begin{tabular}{|l|l|l|}
\hline $\begin{array}{l}\text { Number of paragraph in } \\
\text { questionnaire }\end{array}$ & Variable name factor \\
\hline $1-9$ & $\begin{array}{l}\text { Independent variable (opera- } \\
\text { tions re-engineering) }\end{array}$ & 0.89 \\
\hline $10-18$ & $\begin{array}{l}\text { Attendant variable (overall stra- } \\
\text { tegic performance) of question- } \\
\text { naire }\end{array}$ & 0.93 \\
\hline $1-18$ & $\begin{array}{l}\text { (variables and dimensions of } \\
\text { paragraphs) }\end{array}$ & 0.91 \\
\hline
\end{tabular}

Through the table no. (4.2) we can see that the stability factors of research variables with its all dimensions are high, as the stability factor of all of tool paragraphs was (0.91) and it is a high and acceptable stability average of the purposes of statistical analysis and scientific research.

\subsection{Method of data analysis}

The research depended on statistical package (SPSS_12), to answer the questions and to prove the validity of hypothesis, so it used the following statistical methods:

1. Scale of descriptive statistical, to know the characteristics of research sample and arranging the researched variables and dimensions according to its importance, through the mathematical averages and standard deviations.

2. Multiple Regression Analysis to test the effect of variables and independent dimensions with the attendants.

3. Stepwise Multiple Regression Analysis to test the arrangement of the entry of independent dimensions in the equation of prediction of attendant variable.

4. Analysis of single variance (ANOVA) to determine the relation of personal variables with attendant variable and independent variable.

\section{Chapter III}

\section{Presentation of results}

The following is a presentation of the results of descriptive statistical analysis of data, and it is the value of mathematical averages and standard deviations and the relative importance for all dimensions of research, and paragraphs of each dimension, and taking into consideration that the consecution of used scale in research is as follows:

\begin{tabular}{|l|l|l|l|l|}
\hline Strongly agree & Agree & $\begin{array}{l}\text { Agree with medium } \\
\text { degree }\end{array}$ & disagree & $\begin{array}{l}\text { Strongly } \\
\text { disagree }\end{array}$ \\
\hline 5 & 4 & 3 & 2 & 1 \\
\hline
\end{tabular}

And based on that, the values of mathematical averages of research will be treated to explain the data as follows:

\begin{tabular}{|l|l|l|}
\hline High & Medium & Low \\
\hline 3.5 and more & $2.5 \_3.49$ & $1-2.49$ \\
\hline
\end{tabular}

And based on that, the value of mathematical average of paragraphs is more than (3.5) so the level of visualizations is high and it means the agreement of research sample individuals on the paragraph content, as for the value of mathematical average was (2.5-3.49), so the visualizations level is medium, and if the mathematical average was less than (2.49), the visualizations level will be high. 


\subsection{Answering the research questions}

1. Answering the first question: what are the visualizations of research sample individuals for the level of dominant operations re-engineering, and the extent of the availability of each dimension from its dimensions in Jordanian companies of mining and these dimensions are (administrative settlement, organization culture, and readiness for change).

Table no. (1.3)

Mathematical averages and standard deviations and relative importance for the answers of research sample on the dimensions of operations re-engineering

\begin{tabular}{|c|c|c|c|c|c|c|}
\hline $\begin{array}{l}\text { Sequence } \\
\text { of para- } \\
\text { graphs }\end{array}$ & $\begin{array}{l}\text { Name of } \\
\text { paragraph }\end{array}$ & $\begin{array}{l}\text { Mathe- } \\
\text { matical } \\
\text { average }\end{array}$ & $\begin{array}{l}\text { Standard } \\
\text { devia- } \\
\text { tion }\end{array}$ & $\begin{array}{l}\text { Relative } \\
\text { impor- } \\
\text { tance }\end{array}$ & $\begin{array}{l}\text { Arrange- } \\
\text { ment by } \\
\text { ratio }\end{array}$ & $\begin{array}{l}\text { Level } \\
\text { accord- } \\
\text { ing to } \\
\text { average }\end{array}$ \\
\hline $1-3$ & $\begin{array}{l}\text { Administra- } \\
\text { tive settle- } \\
\text { ment }\end{array}$ & 3.79 & 0.61 & $75.8 \%$ & 1 & High \\
\hline $4-6$ & $\begin{array}{l}\text { Organization } \\
\text { culture }\end{array}$ & 3.46 & 0.70 & $69.2 \%$ & 2 & Medium \\
\hline $7-9$ & $\begin{array}{l}\text { Readiness } \\
\text { for change }\end{array}$ & 3.12 & 0.75 & $62.4 \%$ & 3 & Medium \\
\hline $1-9$ & $\begin{array}{l}\text { Operations } \\
\text { re-engineer- } \\
\text { ing }\end{array}$ & 3.46 & 0.51 & & & Medium \\
\hline
\end{tabular}

Table no. (1.3) shows that the general visualizations of researched of the dimensions independent variable of research (operations re-engineering) were mediocre, as the mathematical average was (3.46) and the standard deviation was (0.51), and the dimension (administrative settlement) was in the first class with a mathematical average (3.79) and relative importance $(75.8 \%)$, then the dimension (organization culture) with a mathematical average (3.46) and relative importance $(69.2 \%)$, and the last class was the dimension (readiness for change) with a mathematical average (3.12) and relative importance $(62.4 \%)$.

And the previous results approved that the dimensions of operations re-engineering (administrative settlement, organization culture, and readiness for change) were realized generally and with medium degree in the Jordanian companies of mining.

1. Visualizations of the individuals of re- search sample for the paragraphs of the dimension (administrative settlement)

Table no. (2.3): mathematical averages and standard deviations for the paragraphs of the dimension (administrative settlement)

\begin{tabular}{|l|l|l|l|l|l|}
\hline $\begin{array}{l}\text { Number } \\
\text { of para- } \\
\text { graph }\end{array}$ & Name of paragraph & $\begin{array}{l}\text { Mathe- } \\
\text { matical } \\
\text { average }\end{array}$ & $\begin{array}{l}\text { Standard } \\
\text { deviation }\end{array}$ & $\begin{array}{l}\text { Relative } \\
\text { impor- } \\
\text { tance }\end{array}$ & $\begin{array}{l}\text { Level for } \\
\text { the aver- } \\
\text { age }\end{array}$ \\
\hline 1 & $\begin{array}{l}\text { I have the technical } \\
\text { experience and } \\
\text { essential skills to } \\
\text { perform work }\end{array}$ & 4.26 & 0.729 & $85.2 \%$ & High \\
\hline 2 & $\begin{array}{l}\text { I have the opportu- } \\
\text { nity to analyze and } \\
\text { personify problems } \\
\text { during the work }\end{array}$ & 3.77 & 0.823 & $75.4 \%$ & High \\
\hline 3 & $\begin{array}{l}\text { I have indepen- } \\
\text { dence and full } \\
\text { freedom in how to } \\
\text { complete my work }\end{array}$ & 3.34 & 0.778 & $66.8 \%$ & Mediocre \\
\hline
\end{tabular}

Table no. (2.3) shows that the visualizations of researched workers on the dimension of administrative settlement were mediocre, and the paragraph "I have the technical experience and essential skills to perform work" was in first class with a mathematical average (4.26) and relative importance $(85.2 \%)$, then the paragraph "I have the opportunity to analyze and personify problems during the work" was in the second class with a mathematical average (3.77) and relative importance $(75.4 \%)$, and the paragraph " I have independence and full freedom in how to complete my work" was in the third class with a mathematical average (3.34) and relative importance $(66.8 \%)$. And we deduced from the previous results that there is a medium degree of satisfaction towards the policies of the companies of mining which aim to empower employees by developing the technical and skillful abilities, and giving them the opportunity to personify the problems and the enough freedom to do works, which reflects positively on the performance and proficiency of companies generally.

\section{Visualizations of the individuals of re- search sample for the paragraphs of the di- mension of organization culture}

Table no. (3.3): mathematical averages and standard deviations for the paragraphs of the dimension (organization culture) 
Khaled Ebdah, GJEBA, 2017; 2:2

\begin{tabular}{|l|l|l|l|l|l|}
\hline $\begin{array}{l}\text { Number of } \\
\text { paragraph }\end{array}$ & $\begin{array}{l}\text { Name of } \\
\text { paragraph }\end{array}$ & $\begin{array}{l}\text { Mathe- } \\
\text { matical } \\
\text { average }\end{array}$ & $\begin{array}{l}\text { Standard } \\
\text { deviation }\end{array}$ & $\begin{array}{l}\text { Relative } \\
\text { impor- } \\
\text { tance }\end{array}$ & $\begin{array}{l}\text { Level for } \\
\text { the aver- } \\
\text { age }\end{array}$ \\
\hline 1 & $\begin{array}{l}\text { The adminis- } \\
\text { tration treats } \\
\text { effectively } \\
\text { with the } \\
\text { obstacles of } \\
\text { its success }\end{array}$ & 3.63 & 0.906 & $72.6 \%$ & High \\
\hline 2 & $\begin{array}{l}\text { The decisions } \\
\text { of admin- } \\
\text { istration } \\
\text { approved its } \\
\text { success in } \\
\text { the company } \\
\text { later }\end{array}$ & 3.38 & 0.785 & $67.6 \%$ & Mediocre \\
\hline 3 & $\begin{array}{l}\text { New ideas } \\
\text { have a high } \\
\text { appreciation } \\
\text { look in the } \\
\text { company }\end{array}$ & 3.37 & 0.905 & $67.4 \%$ & Mediocre \\
\hline
\end{tabular}

Table no. (3.3) shows that the visualizations of researched workers for the dimension of organization culture were mediocre, and the paragraph "the administration treats effectively with the obstacles of its success" was in the first class with a mathematical average (3.63) and relative importance $(72.6 \%)$, then the paragraph (the decisions of administration approved its success in the company later) in the second class with a mathematical average (3.38) and relative importance $(67.6 \%)$, and the paragraph (new ideas have a high appreciation look in the company) in the third class with a mathematical average (3.37) and relative importance (67.4\%), and we deduced from the previous results that there is medium satisfaction degree towards the dominant culture in the company.

3. Visualizations of the individuals of research sample for the paragraphs of the dimension of readiness for change.

Table no. (4.3) : ): mathematical averages and standard deviations for the paragraphs of the dimension (readiness for change).

\begin{tabular}{|l|l|l|l|l|l|}
\hline $\begin{array}{l}\text { Number of } \\
\text { paragraph }\end{array}$ & $\begin{array}{l}\text { Name of para- } \\
\text { graph }\end{array}$ & $\begin{array}{l}\text { Mathe- } \\
\text { matical } \\
\text { average }\end{array}$ & $\begin{array}{l}\text { Standard } \\
\text { deviation }\end{array}$ & $\begin{array}{l}\text { Relative } \\
\text { impor- } \\
\text { tance }\end{array}$ & $\begin{array}{l}\text { Level for } \\
\text { the aver- } \\
\text { age }\end{array}$ \\
\hline 1 & $\begin{array}{l}\text { change in the } \\
\text { company is } \\
\text { moving fast }\end{array}$ & 3.14 & 1.00 & $62.8 \%$ & mediocre \\
\hline 2 & $\begin{array}{l}\text { Change in the } \\
\text { company effects } \\
\text { on the methods } \\
\text { and manners of } \\
\text { work }\end{array}$ & 3.20 & 0.889 & $64 \%$ & Mediocre \\
\hline
\end{tabular}

\begin{tabular}{|l|l|l|l|l|l|}
\hline 3 & $\begin{array}{l}\text { Change in the } \\
\text { company moves } \\
\text { as planned }\end{array}$ & 3.02 & 0.901 & $60.4 \%$ & Mediocre \\
\hline
\end{tabular}

Table no. (4.3) shows that the visualizations of researched workers for the dimension readiness for change were mediocre, and the paragraph "Change in the company effects on the methods and manners of work" was in the first class with a mathematical average (3.20) and relative importance (64\%), then the paragraph " change in the company is moving fast" in the second class with an average (3.14) and relative importance $(62.8 \%)$, and the paragraph "Change in the company moves as planned" was in the third class with a mathematical average (3.02) and relative importance (60.4\%). And we deduced from the previous results that there is a medium satisfaction degree towards the dimension of readiness for change through the movement of mining companies to change with fast steps and as planned for, which reflects positively on performance and proficiency of company generally.

Answer the following question: what is the descending order and relative importance of the dimensions of strategic performance and paragraphs that measure each dimension, from the point of view of researched?

Table no. (5.3): mathematical averages, standard deviations and relative importance of the answers of research sample on the dimensions of strategic performance

\begin{tabular}{|l|l|l|l|l|l|l|}
\hline $\begin{array}{l}\text { Sequence of } \\
\text { paragraphs }\end{array}$ & $\begin{array}{l}\text { Number of } \\
\text { paragraph }\end{array}$ & $\begin{array}{l}\text { Mathe- } \\
\text { matical } \\
\text { average }\end{array}$ & $\begin{array}{l}\text { Stan- } \\
\text { dard } \\
\text { devia- } \\
\text { tion }\end{array}$ & $\begin{array}{l}\text { Rel- } \\
\text { ative } \\
\text { impor- } \\
\text { tance }\end{array}$ & $\begin{array}{l}\text { Ar- } \\
\text { range- } \\
\text { ment } \\
\text { by } \\
\text { ratio }\end{array}$ & $\begin{array}{l}\text { Level } \\
\text { for av- } \\
\text { erage }\end{array}$ \\
\hline $1-3$ & $\begin{array}{l}\text { Financial per- } \\
\text { formance }\end{array}$ & 3.33 & 0.78 & $66.6 \%$ & 3 & $\begin{array}{l}\text { Medio- } \\
\text { cre }\end{array}$ \\
\hline $4-6$ & $\begin{array}{l}\text { Operational } \\
\text { performance }\end{array}$ & 3.36 & 0.67 & $67.2 \%$ & 2 & $\begin{array}{l}\text { Medio- } \\
\text { cre }\end{array}$ \\
\hline $7-9$ & $\begin{array}{l}\text { Competitive } \\
\text { performance }\end{array}$ & 3.52 & 0.80 & $70.4 \%$ & 1 & High \\
\hline $1-9$ & $\begin{array}{l}\text { Strategic per- } \\
\text { formance }\end{array}$ & 3.40 & 0.61 & & & $\begin{array}{l}\text { Medio- } \\
\text { cre }\end{array}$ \\
\hline
\end{tabular}

Table no. (5.3) shows that the general visualizations of researched for the dimensions of attendant variable of research (strategic performance) were mediocre, as the mathematical average was (3.40) and the standard deviation was (0.61), and the dimension of (competitive performance) was in the first class with a mathematical average (3.52) and relative importance $(70.4 \%)$, then the (operational performance) 
with a mathematical average (3.36) and relative importance $(67.2 \%)$, and the dimension (financial performance) came in the third and last class with a mathematical average (3.33) and relative importance $(66.6 \%)$. And the previous results approved that the dimensions of strategic performance (financial performance, operational performance, competitive performance) were realized generally and with medium degree in the Jordanian companies of mining.

\section{Visualizations of individuals of research sample for the paragraphs of the dimension of financial performance}

Table no. (6.3): mathematical averages and standard deviations of the paragraphs of the dimension of financial performance.

\begin{tabular}{|l|l|l|l|l|l|}
\hline $\begin{array}{l}\text { Number of } \\
\text { paragraph }\end{array}$ & $\begin{array}{l}\text { Name of para- } \\
\text { graph }\end{array}$ & $\begin{array}{l}\text { Mathe- } \\
\text { matical } \\
\text { average }\end{array}$ & $\begin{array}{l}\text { Standard } \\
\text { deviation }\end{array}$ & $\begin{array}{l}\text { Relative } \\
\text { impor- } \\
\text { tance }\end{array}$ & $\begin{array}{l}\text { Level for } \\
\text { the aver- } \\
\text { age }\end{array}$ \\
\hline 1 & $\begin{array}{l}\text { The company } \\
\text { is working on } \\
\text { reducing the } \\
\text { financial risks } \\
\text { which it faces }\end{array}$ & 3.41 & 0.88 & $68.2 \%$ & Mediocre \\
\hline 2 & $\begin{array}{l}\text { The company } \\
\text { is working on } \\
\text { adhering to } \\
\text { the laws and } \\
\text { the dictated } \\
\text { financial legis- } \\
\text { lations }\end{array}$ & 3.26 & 1.05 & $65.2 \%$ & Mediocre \\
\hline 3 & $\begin{array}{l}\text { The company } \\
\text { announced } \\
\text { the import- } \\
\text { ant financial } \\
\text { reports which } \\
\text { related to its } \\
\text { works }\end{array}$ & 3.33 & 1.01 & $66.6 \%$ & Mediocre \\
\hline
\end{tabular}

Table no. (6.3) shows that the visualizations of researched workers for the dimension of financial performance were mediocre, and the paragraph" The company is working on reducing the financial risks which it faces" was in the first class with a mathematical average (3.41) and relative importance $(68.2 \%)$, then the paragraph " The company announced the important financial reports which related to its works" in the second class with an average (3.33) and relative importance $(66.6 \%)$, and the paragraph "The company is working on adhering to the laws and the dictated financial legislations" was in the third class with a mathematical average (3.26) and relative importance $(66.2 \%)$. And we deduced from the previous results that there is a medium satisfaction degree towards the dimension of financial performance through the commitment of the company to the laws and the dictated financial legislations and announcing its financial reports, also continuous working on reducing the financial risks which it faces.

\section{Visualizations of individuals of research sample for the paragraphs of the dimension of operational performance}

Table no. (7.3): mathematical averages and standard deviations of the paragraphs of the dimension of operational performance.

\begin{tabular}{|l|l|l|l|l|l|}
\hline $\begin{array}{l}\text { Number of } \\
\text { paragraph }\end{array}$ & $\begin{array}{l}\text { Name of para- } \\
\text { graph }\end{array}$ & $\begin{array}{l}\text { Mathe- } \\
\text { matical } \\
\text { average }\end{array}$ & $\begin{array}{l}\text { Standard } \\
\text { deviation }\end{array}$ & $\begin{array}{l}\text { Relative } \\
\text { impor- } \\
\text { tance }\end{array}$ & $\begin{array}{l}\text { Level for } \\
\text { the aver- } \\
\text { age }\end{array}$ \\
\hline 1 & $\begin{array}{l}\text { The company } \\
\text { is working on } \\
\text { following the } \\
\text { methodology } \\
\text { of continuous } \\
\text { improvement } \\
\text { of the quality } \\
\text { of presented } \\
\text { services }\end{array}$ & 3.25 & 0.94 & $65 \%$ & Mediocre \\
\hline 2 & $\begin{array}{l}\text { The company } \\
\text { seeks to achieve } \\
\text { the efficient } \\
\text { using of its avail- } \\
\text { able resources } \\
\text { continuously }\end{array}$ & 3.37 & 1.01 & $67.4 \%$ & Mediocre \\
\hline 3 \\
$\begin{array}{l}\text { There is an inter- } \\
\text { esting in custom- } \\
\text { ers' problems } \\
\text { and working on } \\
\text { finding solutions } \\
\text { for it. }\end{array}$ & 3.47 & 0.89 & $69.4 \%$ & Mediocre \\
\hline
\end{tabular}

Table no. (7.3) shows that the visualizations of researched workers for the dimension of operational performance were mediocre, and the paragraph" There is an interesting in customers' problems and working on finding solutions for it" was in the first class with a mathematical average (3.47) and relative importance (69.4\%), then the paragraph "The company seeks to achieve the efficient using of its available resources continuously " in the second class with an average (3.37) and relative importance (67.4\%), and the paragraph " The company is working on following the methodology of continuous improvement of the quality of presented services "was in the third class with a mathematical average (3.25) and relative importance (65\%). And we deduced from the previous results that there is a medium satisfaction degree towards the dimension of operational performance through the movement of the mining companies to use the available re- 
sources efficiently in addition to continuous improvement of quality of presented services, and attention to customers' problems and working on solving it.

3. Visualizations of individuals of research sample for the paragraphs of the dimension of competitive performance.

Table no. (8.3): mathematical averages and standard deviations of the paragraphs of the dimension of competitive performance.

\begin{tabular}{|l|l|l|l|l|l|}
\hline $\begin{array}{l}\text { Number of } \\
\text { paragraph }\end{array}$ & $\begin{array}{l}\text { Name of para- } \\
\text { graph }\end{array}$ & $\begin{array}{l}\text { Mathe- } \\
\text { matical } \\
\text { average }\end{array}$ & $\begin{array}{l}\text { Standard } \\
\text { deviation }\end{array}$ & $\begin{array}{l}\text { Relative } \\
\text { impor- } \\
\text { tance }\end{array}$ & $\begin{array}{l}\text { Level for } \\
\text { the aver- } \\
\text { age }\end{array}$ \\
\hline 1 & $\begin{array}{l}\text { The company } \\
\text { seeks to enter } \\
\text { foreign markets } \\
\text { to market its } \\
\text { products }\end{array}$ & 3.61 & 0.91 & $72.2 \%$ & High \\
\hline 2 & $\begin{array}{l}\text { The company } \\
\text { depends on } \\
\text { its customers' } \\
\text { opinions as a } \\
\text { priority to per- } \\
\text { form its works }\end{array}$ & 3.59 & 0.99 & $71.8 \%$ & High \\
\hline 3 & $\begin{array}{l}\text { The company } \\
\text { is working } \\
\text { on increasing } \\
\text { the amounts } \\
\text { allocated for } \\
\text { research to sup- } \\
\text { port and devel- } \\
\text { op its products } \\
\text { and marketing } \\
\text { it continuously }\end{array}$ & 3.35 & 1.07 & $67 \%$ & Mediocre \\
\hline
\end{tabular}

Table no. (8.3) shows that the visualizations of researched workers for the dimension of competitive performance were mediocre, and the paragraph" The company seeks to enter foreign markets to market its products" was in the first class with a mathematical average (3.61) and relative importance $(72.2 \%)$, then the paragraph "The company depends on its customers' opinions as a priority to perform its works " in the second class with an average (3.59) and relative importance $(71.8 \%)$, and the paragraph "The company is working on increasing the amounts allocated for research to support and develop its products and marketing it continuously "was in the third class with a mathematical average (3.35) and relative importance (67\%). And we deduced from the previous results that there is a medium satisfaction degree towards the dimension of competitive performance through the movement of the mining companies to enter the foreign markets, and allocating sums for re- search and supporting, developing and marketing its products, and working on benefiting from the opinions of customers to achieve a competitive advantage in the field of mining industry.

\subsection{Test results of research hypotheses}

First main hypothesis: there is a statistically significant effect at the significance level $(a<0.05)$ of the dimensions of operations re-engineering (administrative settlement, organization culture, readiness for change) in strategic performance.

Table no. (9.3): influential relationship between operations re-engineering and strategic performance.

\begin{tabular}{|c|c|c|c|c|c|}
\hline \multirow{2}{*}{ Model } & \multicolumn{2}{|c|}{ Unstandard Coefficient } & $\begin{array}{c}\text { Standard } \\
\text { Coefficient }\end{array}$ & \multirow{2}{*}{ T } & \multirow{2}{*}{ Sig. } \\
\cline { 2 - 4 } & B & Std. Error & Beta & & \\
\hline Constant & 1.167 & 0.519 & - & 2.250 & 0.029 \\
\hline $\begin{array}{c}\text { Operations } \\
\text { re-engineering }\end{array}$ & 0.646 & 9.149 & 0.536 & 4.358 & 0.000 \\
\hline
\end{tabular}

Table (10.3): Analysis of variance for operations re-engineering and strategic performance.

\begin{tabular}{|c|c|c|c|c|c|}
\hline Model & $\begin{array}{c}\text { Sum Of } \\
\text { Squares }\end{array}$ & Df & Mean Square & F & Sig. \\
\hline Regression & 5.200 & 1 & 5.200 & 18.994 & 0.000 \\
\hline Residual & 12.867 & 47 & 0.274 & - & - \\
\hline Total & 18.067 & 48 & - & - & - \\
\hline
\end{tabular}

$R^{2}=0.288$

$R^{2}(\operatorname{adj})=0.273$

Table no. (9.3) indicates that there is a significant effect relationship between operations re-engineering and strategic performance. And table no. (10.3) shows us the effect model according to analysis of variance that leads us to accept the first main hypothesis. As the average of $(f=18.994)$ which calculated below a significant level (0.05) and with a degree of freedom (1.47). and it is bigger than the tabular value, but the determination coefficient which expresses the ability of independent variables gathered to interpret the attendant variable (strategic performance) has a low value that arrives at $\left(R^{2}=0.288\right)$, and this means that $(28.8 \%)$ from the independent variables have explained the changes of strategic performance.

And the previous requires the acceptance of 
main hypothesis which dictates that there is a statistically significant effect at the significance level $(a<0.05)$ for the dimensions of operations re-engineering gathered in strategic performance of mining companies.

First sub-hypothesis: there is a relation with statistically significance at significance level $(a<0.05)$ between administrative settlement and strategic performance in the company.

Table no. (11.3): The effect of administrative settlement on strategic performance

\begin{tabular}{|c|c|c|c|c|c|}
\hline \multirow{2}{*}{ Model } & \multicolumn{2}{|c|}{ Unstandard Coefficient } & $\begin{array}{c}\text { Standard } \\
\text { Coefficient }\end{array}$ & T & Sig. \\
\cline { 2 - 4 } & B & Std. Error & Beta & & \\
\hline Constant & 2.136 & 0.534 & - & 4.000 & 0.000 \\
\hline $\begin{array}{c}\text { Administrative } \\
\text { settlement }\end{array}$ & 0.334 & 0.139 & 0.331 & 2.405 & 0.020 \\
\hline
\end{tabular}

Table no. (11.3) shows that the administrative settlement practices a significant effect on strategic performance. Table no. (12.3) of the analysis of variance also shows that the model is significant according to the calculated value of $F$ which arrives at (5.783) and it is bigger than tabular value at the significant level (0.05) and with two degrees of freedom (1.47). And the interpretive ability of this model was law according to the value $R^{2}=0.110$, and this indicates to the ability of independent variable on explaining $(11 \%)$ from the differences of attendant variable.

Table no. (12.3): analysis of the variance of effect model between administrative settlement and strategic performance.

\begin{tabular}{|c|c|c|c|c|c|}
\hline Model & $\begin{array}{c}\text { Sum Of } \\
\text { Squares }\end{array}$ & Df & Mean Square & F & Sig. \\
\hline Regression & 1.979 & 1 & 1.979 & 5.783 & 0.020 \\
\hline Residual & 16.087 & 47 & 0.342 & - & - \\
\hline Total & 18.067 & 48 & - & - & - \\
\hline
\end{tabular}

And based on the presented, it is clear to us the acceptance of the first sub-hypothesis from the first main hypothesis which contains the existence of significant effect between the administrative settlement and strategic performance of the company but the effect degree is law.

Second sub-hypothesis: there is a relation with statistically significance at significance level $(a<0.05)$ between organization culture and strategic performance in company.

Table no. (13.3): the effect of organization culture on strategic performance

\begin{tabular}{|c|c|c|c|c|c|}
\hline \multirow{2}{*}{ Model } & \multicolumn{2}{|c|}{ Unstandard Coefficient } & $\begin{array}{c}\text { Standard } \\
\text { Coefficient }\end{array}$ & \multirow{2}{*}{ S } & \\
\cline { 2 - 4 } & B & Std. Error & Beta & & \\
\hline Constant & 2.453 & 0.427 & - & 5.750 & 0.000 \\
\hline $\begin{array}{c}\text { Organization } \\
\text { culture }\end{array}$ & 0.275 & 0.121 & 0.315 & 2.273 & 0.028 \\
\hline
\end{tabular}

(24)

The results of the table (13.3) indicates that there is a significance effect of organization culture on strategic performance, and that exactly what the second sub-hypothesis dictates to from the first main hypothesis, from the existence of an effect relation between organization culture and strategic performance. And in the next table (14.3) of variance analysis of organization culture, the results show the level of significance model. As it appeared that the model is significant according to the calculated value $(F=5.168)$ and it is bigger than its tabular value on the tow degrees of freedom (1.47) and with significant level (0.05), as well as the value of determination coefficient was $\left(R^{2}=0.099\right)$ and it is a low value. As it indicates to the ability of independent variable on explaining (9\%) from the differences in the attendant variable (strategic performance).

Table no. (14.3): analysis of the variance of effect model between organization culture and strategic performance.

\begin{tabular}{|c|c|c|c|c|c|}
\hline Model & Sum Of Squares & Df & Mean Square & $F$ & Sig. \\
\hline Regression & 1.790 & 1 & 1.790 & 5.168 & 0.028 \\
\hline Residual & 16.277 & 47 & 0.346 & - & - \\
\hline Total & 18.067 & 48 & - & - & - \\
\hline
\end{tabular}

And based on the presented, it is clear to us the acceptance of the second sub-hypothesis from the first main hypothesis which contains the existence of significant effect between organization culture and strategic performance but the effect degree is law.

Third sub-hypothesis: there is a relation with statistically significance at significance level $(a<0.05)$ between readiness for change and strategic performance in company. 
Table no. (15.3): analysis of influential relationship between readiness for change and strategic performance.

\begin{tabular}{|c|c|c|c|c|c|}
\hline \multirow{2}{*}{ Model } & \multicolumn{2}{|c|}{ Unstandard Coefficient } & \multirow{2}{*}{$\begin{array}{c}\begin{array}{c}\text { Standard } \\
\text { Coefficient }\end{array} \\
\text { Beta }\end{array}$} & \multirow{2}{*}{ T } & \multirow{2}{*}{ Sig. } \\
\hline & B & Std. Error & & & \\
\hline Constant & 2.043 & 0.326 & - & 6.275 & 0.000 \\
\hline $\begin{array}{l}\text { Readiness for } \\
\text { change }\end{array}$ & 0.436 & 0.101 & 0.531 & 4.296 & 0.000 \\
\hline
\end{tabular}

The results of the previous table (15.3) show that readiness for change practices a significant effect on strategic performance. And this confirms us the acceptance of the third sub-hypothesis from the first main hypothesis which dictates to the existence of significant effect between readiness for change and strategic performance of the company. And the results of descending in the table (16.3) show that the model is significant according to the calculated value (F-18.459) on a significant level (0.05) and with two degrees of freedom (1.47).

Table no. (16.3): analysis of the variance of effect model between readiness for change and strategic performance.

\begin{tabular}{|c|c|c|c|c|c|}
\hline Model & Sum Of Squares & Df & Mean Square & $\mathrm{F}$ & Sig. \\
\hline Regression & 5.095 & 1 & 5.095 & 18.459 & 0.000 \\
\hline Residual & 12.972 & 47 & 0.276 & - & - \\
\hline Total & 18.067 & 48 & - & - & - \\
\hline
\end{tabular}

$\mathrm{R}^{2=.420} \quad \mathrm{R}^{2}(\mathrm{adj})=.173$

(25)

As for the determination coefficient for this variable (readiness for change) arrived at $\left(R^{2}=0.282\right)$ and it is also a relatively low value which indicates to the ability of independent variable on explaining $(28 \%)$ from the differences of attendant variable.

And based on the presented, it is clear to us the acceptance of the third sub-hypothesis from the first main hypothesis which contains the existence of significant effect between readiness for change and strategic performance of the company, but the effect degree is law.

Second main hypothesis: " there are differences with statistically significance on the significance level $(a>0.05)$ in strategic performance of the employees in Jordanian mining companies which attributed to the functional and personal variables (gender, age, practical experience, scientific qualification, administrative level).

To test this hypothesis, an analysis of one-variance has used the visualizations of sample individuals of strategic performance which attributed to the functional and personal variables (gender, age, practical experience, scientific qualification, administrative level):

Table no. (17.3): analysis of one-variance of the researched visualizations about strategic performance depending on the functional and personal variables (gender, age, practical experience, scientific qualification, administrative level)

\begin{tabular}{|c|c|c|c|c|c|}
\hline $\begin{array}{l}\text { Personal } \\
\text { variable }\end{array}$ & $\begin{array}{c}\text { Source of } \\
\text { contrast }\end{array}$ & $\begin{array}{c}\text { Sum } \\
\text { squares }\end{array}$ & $\begin{array}{c}\text { Average of } \\
\text { squares }\end{array}$ & Value of $(F)$ & $\begin{array}{l}\text { Level of sig- } \\
\text { nificance }\end{array}$ \\
\hline Gender & $\begin{array}{l}\text { Among } \\
\text { groups } \\
\text { Inside } \\
\text { groups }\end{array}$ & $\begin{array}{l}3.502 \\
7.886\end{array}$ & 0.269 & **1.196 & 0.323 \\
\hline Age & $\begin{array}{l}\text { Among } \\
\text { groups } \\
\text { Inside } \\
\text { groups }\end{array}$ & $\begin{array}{l}17.271 \\
40.729\end{array}$ & $\begin{array}{l}1.329 \\
1.164\end{array}$ & **1.142 & 0.360 \\
\hline $\begin{array}{c}\text { Scientific } \\
\text { qualifica- } \\
\text { tion }\end{array}$ & $\begin{array}{l}\text { Among } \\
\text { groups } \\
\text { Inside } \\
\text { groups }\end{array}$ & $\begin{array}{l}18.928 \\
22.419\end{array}$ & 1.456 & ${ }^{*} 2.273$ & 0.027 \\
\hline $\begin{array}{l}\text { Practical } \\
\text { experience }\end{array}$ & $\begin{array}{l}\text { Among } \\
\text { groups } \\
\text { Inside } \\
\text { groups }\end{array}$ & $\begin{array}{l}22.012 \\
28.805\end{array}$ & 1.693 & $* 2.057$ & 0.045 \\
\hline $\begin{array}{l}\text { Administra- } \\
\text { tive level }\end{array}$ & $\begin{array}{l}\text { Among } \\
\text { groups } \\
\text { Inside } \\
\text { groups }\end{array}$ & $\begin{array}{l}14.859 \\
18.529\end{array}$ & 1.143 & ${ }^{*} 2.159$ & 0.035 \\
\hline
\end{tabular}

*with statistical significance on the significance level $(a<0.05)$

** Without statistical significance on the significance level $(a<0.05)$

The results in the table (17.3) show the visualizations of researched about strategic performance according to the functional and personal variables, as it is noted from the table that there are no statistical significant differences between gender, age and strategic performance which means rejection of sub-hypothesis that believes in the existing of statistical significance differences on the significance level $(a>0.05)$ in strategic 
Khaled Ebdah, GJEBA, 2017; 2:2

performance in mining companies which attributed to the functional and personal variables (gender, age), with the significance of decreasing of the value $(F)$ than its tabular value. The table no. (17.3) also shows that there are statistical significance differences between scientific qualification, practical experience and strategic performance of the company with the significance of increasing of the value $(F)$ on its tabular value, which means acceptance of sub-hypothesis that believed in the existence of statistical significance differences on the significance level $(a>0.05)$ in strategic performance in mining companies which attributed to the variables, scientific qualification, practical experience and administrative level.

\section{Chapter IV}

\section{Conclusion, discussion and recommenda- tions}

\subsection{Conclusion}

In this research, we tried to recognize the effect of re-engineering of administrative operations (engistrative) on strategic performance in Jordanian companies of mining, and recognizing on the extent of the availability of the dimensions of administrative operations re-engineering, and strategic performance in these companies. and the research found an important effect with statistical significance on the significance level $(a<0.05)$ of the dimensions of operations re-engineering (administrative settlement, organization culture, readiness for change) on strategic performance of the employees in Jordanian companies of mining, as the dimensions of operations re-engineering jointly have explained about $\left(R^{2}=28.8 \%\right)$ from the variance in strategic performance. the research also found statistical significance differences in the level of strategic performance attributed to the functional and personal variables (scientific qualification, practical experience and administrative level).

\subsection{Discussion of results:}

1.The research found that the visualizations of sample individuals of operations re-engineering with its different dimensions, were positive and mediocre, as the mathematical average of the operations re-engineering variable as a whole was (3.46) and with standard deviation (0.51).
And the dimension of (administrative settlement) came in the first class in terms of importance, as the mathematical average was (3.79), then the dimension (readiness for change) came in the last class with a mathematical average (3.12).

2. statistical results indicated that the mathematical average of the paragraphs of the dimension (administrative settlement) was (3.79), and with relative importance $(75.8 \%)$, and this indicates that the organization importance of the dimension of administrative settlement of employees was high, as the most important paragraphs are that the employees have the technical experience and necessary skills to perform the work. as the policies of mining companies are to give the opportunity to the employees to improve their technical skills, as the administrations of these companies pay a special attention to this subject for its great importance in furbishing the experiences of employees and showing their talents and technical skills in its finest form, which reflects on the performance of the companies and its accomplishment and its differentiation in presenting services.

3. statistical results showed that the mathematical average of the paragraphs of the dimension (organization culture) was mediocre, as it arrived at (3.46) and in the second class in terms of importance compared to the other dimensions of operations re-engineering, as its relative importance was $(69.2 \%)$. and this can be explained as an attempt of the mining companies to create a positive and strong organizational culture which facilitates the process of operations re-engineering and enhances the stability and balance of organization as a social system, and works as a guide to the behavior of individual and community, and as a result contributes to achieve a high performance level by a group of cultural components, such as encouraging the new ideas, innovation,creation and change. and dealing with obstacles of work through a clear vision, clear direction, values and standards which achieve the require targets.

4. The results of the research showed that the visualizations of researched of the dimension (readiness for change) were mediocre, as the total mathematical average of the dimension of readiness for change was (3.12), and came in the third and last class in terms of its importance, 
as its relative importance was $(62.4 \%)$.

and the most important paragraph as that change in the company effects on its ways and methods of work, and this explains that change raises productive proficiency, and opening the door of innovation and creation, and changing the administrative operations in its all forms and on the whole levels towards a work environment more dynamic.

5. The research reached to a good level of the dimensions of research attendant variable (strategic performance) which were mediocre as the mathematical average was (3.40), and the dimension of (competitive performance) was in the first class with a mathematical average (3.52) and relative importance $(70.4 \%)$, and the dimension of (financial performance) came in the third and last class with a mathematical average (3.33) and relative importance (66.6\%). and the previous results denote that the dimensions of strategic performance (financial performance, operational performance, competitive performance) have been available generally in Jordanian companies of mining and with a medium degree.

6. The results showed a statistical significance effect on the significance level $a<0.05$ of the dimensions of operations re-engineering jointly in strategic performance of mining companies.

7. The results showed a significant effect between administrative settlement and strategic performance of mining companies but the effect degree is law.

8. The results showed a relation with statistical significance on the significance level $a<0.05$ between organization culture and strategic performance of mining companies.

9. The results showed a relation with statistical significance on the significance level $a<0.05$ between readiness for change and strategic performance of mining companies.

10. The results showed that there are no statistical significance differences on the significance level $(a>0.05)$ in strategic performance of mining companies which attributed to personal and functional variables (gender, age), the results also showed that there are statistical significance differences on the significance level (a>0.05) in strategic performance of mining companies which attributed to the variables of scientific qualification, practical experience and administrative level.

\subsection{Recommendations}

Based on the results of the research, it recommends with the following:

1. Work on the application of the concept of operations re-engineering, to increase its ability on improving strategic performance, by supporting the creators, stimulating them, adopting their ideas, assigning them with works that shows their intellectual challenges and sharpen their spirit of creation, it also encourages them to get out of the typical specified thinking, to a diverse, original and new thinking, and changing the methods of work, its ways and procedures.

2. Increasing attention to the human element and work on acquiring it the appropriate technical skills which adapted to work requirements.

3. Senior management encourages employees to try new methods of work and showing the creative ideas and using it in work with the necessity for the management to be the example in adopting creation and innovation and work on coloring the work with something of challenge and outing of the ordinary.

4. as for the level of strategic performance of the research sample tends to be high, as the value of mathematical average of the strategic performance of employees (3.40), so an appropriate attention must be given to raise this level and increase it, and this requires work on discovering their obstacles of performance by doing more researches about this side and work on removing it or decreasing it.

5. Doing more researches about operations re-engineering to include dimensions broader than the dimensions of research (such as commitment of senior management of the philosophy of engistrative and supporting its application, communication, etc.), and determining its effect on strategic performance inside the organization because the importance of the subject.

\section{References}


Khaled Ebdah, GJEBA, 2017; 2:2

Abu Bakr, Mustafa Mahmud (2000), "the evidence of strategic thinking and preparation of strategic plan", University House for Publishing, Alexandria, Egypt.

AIKhalifa, Ziad Said, (2008),"Organizational culture and its role in raising the functional performance level", unpublished master thesis, Naif Arab University for security science, Kingdom of Saudi Arabia.

AIRAbiq, Mohamed (2004), "influential factors in the functional performance effectiveness of the security leaders- an applied research on internal officers in the authority of establishments' security and special force for road safety", unpublished master thesis, Naif Academy for security science, Kingdom of Saudi Arabia.

AIRifai, Mamduh Abdul-Aziz, (2006), "operations re-engineering, faculty of commerce, Ain-Shams University, Journal of commercial researches and studies", available on the web site: www. dr-mamdouhrefaiy.com/book/e3adt_handast. doc, date of entry $1 \backslash 9 \backslash 2016$

AlZaydaniiyn, Mohamed Matar, (2006), "the effect of administrative settlement on the application of the principles of total quality in Jordanian governmental and financial institutions", unpublished master thesis, Mu'tah University, business administration faculty, Kark, Jordan.

Al Shahrani, Safia bent Mohamed bin Qassim,(2007), "re-engineering of the methods of university education to face the requirements of the information culture era, suggested model for UMM AI Qura University", unpublished master thesis, UMM Al Qura University, Makah, Kingdom of Saudi Arabia.

Al Sagheer, Fahd bin Mohamed, (2002), "organizational climate and its effect on the employees performance in security devices", unpublished master thesis, Naif Arab University for security science, Kingdom of Saudi Arabia.

Al Safw, Riad Diaa' Aziz (2009) "the elements of operations strategic and its effect on strategic performance" unpublished master thesis, Al Mosul University, Iraq.

Al Otaibi, Saad Marzuq and Al Hammali, Rashed Mohamed, (2004), "re-engineering of administrative operations (engistrative) in public sector, critical success factors", Kingdom of Saudi Arabia, First national conference of quality, 17 may 200428 rabii awal 1225 HGRI, P.15-26.

Abdul Hafiz, Ahmed Saleh, (2003), "practical reference to apply engistrative curriculum", Dar Wael for Publishing and Distribution, Amman, Jordan.
Al Adaily, Nasser, (1995), "human and organizational behavior (comparative total perception)", public administration institution, Riyadh, Saudi Arabia.

Al Qotb, Mohiuddin Yahiya Tawfiq, (2002), "strategic choice and its effect on achieving the competitive advantage", unpublished doctorate thesis, faculty of administration and economics, Mustansiriya University, Iraq.

Al Louzi, Moussa, (2002), “ organizational development: new concepts and principals", Dar Wael for Publishing and Distribution, Amman, Jordan.

Al Morsy, Jamaleddin and Thabet, Abdurrahman Idris, (2002), "organizational behavior: theories, models and practical application for behavior management in the organization", University House for Publishing, Cairo, Egypt.

Burnes, Bernard, (2000), "Managing Change: A Strategic Approach to Organizational Dynamics", 3rd edition, Harlow, England: Prentice Hall.

Bourne, Deboss, (2006(, "Reframing resistance to change experience from general motors Poland", International journal of human resource management, vol.17, Issue 12.

Chiplunkar, Chandrashekhar, Deshmukh, S.G. \& Chattopadhyay, R., (2008), "Application of Principles of Event Related Open Systems to Business Process Reengineering", Computer \& Industrial Engineering, Vol. 45, Issue 3, pp347-374.

Daft, R., A. (2001),"Organizational Behavior" (5th) Dryden Press. Harcourt College Publishers. USA

Effendi, Attia Hussein (2003) " enablement of employees: entrance to continuous improvement and development", Arabic organization for administrative development, Cairo, Egypt.

Francis, D \& Kabir, H (2008) Reengineering Human Resources Management in University, Strategic Management Journal, Vol (28), No (12), pp: 1319-1350.

Glunk, U., \& Wilderom, C., (2000), Organizational Effectiveness. www.stbtdc.org

Hussein, Salama Abdul Azim, (2009), "re-engineering revolution, new entrance to the education system", New University House, Alex, Egypt.

Hanoon, Nadia Murad, (2010), "the degree of using the administrative re-engineering method in the practice of administrative operations in the governmental schools in the governorates of West Side, from the point of view of directors and directresses", Islamic University journal (human 
studies series), Folder(16), number(1), P.713755.

Hammer, M. and Champy, J. (1993), Reengineering the Corporation: A Manifesto for Business Revolution, Harper Business, and New York, NY.

Hammer, M. and Stanton, A. (1995), the Re-engineering Revolution: Handbook, Harper Business, and New York, NY.

Harvey, Don \& Brown, Donald R., (2001), an Experiential Approach to Organization Development, 6th Edition, New Jersey: Prentice Hall.

Lockaby III, A. and Smith, W., (1997). A strategic alignment approach for effective business process reengineering: Linking strategy, processes and customers for competitive advantage. International Journal of Production Economics, Special Issue on Business Process Reengineering 50, pp. 141-153.

Khodairy, Ahmed Mohsen(2003), "Change administration: economic entrance to the administrative psychology to deal with the present variables to achieve perfection and excellence to the projects in the future", "Al-Reda series for administrative development, Dar Al-Reda for Publishing. Damascus, Syria.

Khawaja, Majid Abdul-Aziz Eissa, (2008), “development of the model of re-engineering of administrative operations in the vocational training institution", unpublished master thesis, Jordan, business administration faculty, Jordanian university.

Smith, Douglas, (2001), “ management of personal and performance change: principles, strategies, visions", T (1), Translation: Abdul Hakim Ahmed AlKhozami, ITRAK for Printing and Publishing.

Morris, K. F. and Roben, C. S. (1995), " The fundamentals of change management", in Nadler, D. A., Shawm R. B., Walton, A. E. and Associates (Eds)m Discontinuous change: leading organizational transformation, Jossey Bass, San Francisco

Mische, K., \& Bennis, W. (1996). Business process orientation: Gaining the Business competitive advantage. Delray Beach: St. Lucie Press

Maclntosh, R. (2003). BPR: Alive and well in the public sector. International Journal of Operations \& Production Management, 23(3), 327-344.

Naif, Asaad Qazzim, (2007), "relation between knowledge management and essential ability and its effect on strategic performance", unpublished doctorate thesis, faculty of administration and economics, Mustansiriya University.

Noy, Taha Hussein, (2011), "technological development and its role in activating knowledge management in business organization: status of general directorate of Algeria telecom institution", doctorate thesis, Algeria University 3, Algeria.

Olalla, N, (2005), Business process management: A review and evaluation. Journal of Information Management, Vol. (28), No (5),

Obeid, Abdul Salam Ibrahim, (2003), "philosophy of management of total quality and its effect on strategic performance", unpublished doctorate thesis, faculty of administration and economics, Baghdad University.

Tang, K.H. and Zairi, M. (1998), benchmarking quality implementation in a service context: a comparative analysis of financial services and institutions of higher education. Part I. Total Quality Management, Vol.9, No.6, pp.407-20.

Tennat, C. (2005). The application of business process reengineering in the U.K. TQM Magazine, Vol (17), No (6),

Thomas, C, (1997), Business Process Reengineering, Myth \& Reality, 3 rd Ed., Kogan. Page, London

Zureiqat, Khaled and AlKharsha, Yassin, (2010), " the effect of organizational education on enhancing the dimensions of re-engineering of administrative operations (engistrative) in the Jordanian public institutions, Jordanian magazine of business administration, folder (8), number (3), P.124-141.

Zairi, M. (1997). Business process management: a boundary less approach to modern competitiveness. Business Process Management Journal, 3(1), $64-80$

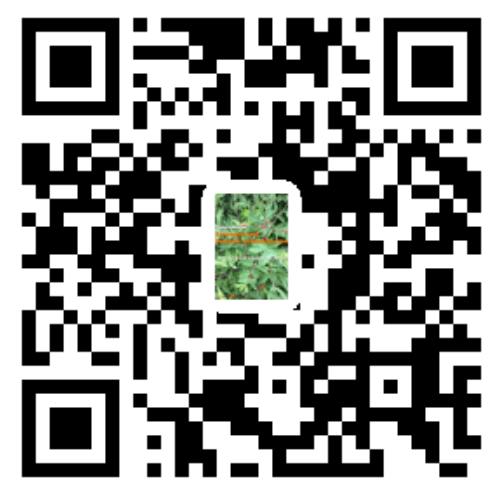

